\title{
NOTES
}

\section{Uniform Adoption Laws: A Public Health Perspective}

\author{
Deborah E. Crum*
}

\section{ABSTRACT}

Adoption has long been seen as the "perfect solution" for numerous parties. Traditionally viewed, adoption is no more than a social service procedure; however, viewed more broadly, adoption provides a solution to the public health concerns of unplanned pregnancies and foster care populations. In the United States, the power to establish and administer the legal and procedural systems applicable to the adoption process is granted to the individual states, due to their responsibility to regulate the welfare of children. Therefore, like other areas of family law, adoption is a state-created statute. Conflicts between states are not uncommon because of the discrepancies in adoption laws amongst the states. These discrepancies between different state adoption laws lead to confusion, forum shopping, and most importantly, negative attitudes and reactions toward adoption. Ultimately, these discrepancies hurt the only innocent party involved: children in need of a family. As a solution to multiple public health concerns, adoption laws would benefit from a uniform adoption act.

This Note will examine the extensive issues resulting from the discrepancies between state adoption laws and address how a uniform adoption act could significantly promote adoption as a viable solution to two public health concerns: the increasing number of unplanned pregnancies and the significant number of children in foster care awaiting permanent

* Candidate for J.D., University of Pittsburgh School of Law, 2013. Senior Managing Editor, Pittsburgh Journal of Environmental and Public Health Law, 2012-13.

\section{P a g e $\mid \mathbf{1 2 7}$}

ISSN 2164-7976 (online) • DOI 10.5195/pjephl.2013.42

http://pjephl.law.pitt.edu 
placements. Section I explores public health concerns that would benefit from a uniform adoption act. Section II discusses adoption laws as state responsibilities and addresses the major consequences of having different state adoption laws. Section III details past efforts to overcome the differences in state adoption laws, including the Uniform Adoption Act of 1994. Finally, Section IV analyzes the need for some form of uniform adoption laws if adoption is to remain a viable solution to public health concerns, namely the increasing number of unplanned pregnancies and significant number of children in the foster care system awaiting adoption.

P a g e | 128

ISSN 2164-7976 (online) • DOI 10.5195/pjephl.2013.42

http://pjephl.law.pitt.edu 


\section{INTRODUCTION}

Baby Emma was born on February 10, 2009. The next morning, her father John Wyatt rushed to the hospital, excited to meet his newborn daughter. Unfortunately, John never got to see his little girl because the mother agreed to an adoption without his consent. Colleen Fahland, Wyatt's ex-girlfriend, got pregnant at the age of nineteen while the couple was dating. ${ }^{1}$ According to Wyatt, he expressed an interest in raising the baby every time the parties talked. In spite of this, Fahland had decided to consent to the adoption of Baby Emma prior to her birth. She even retained Act of Love/Alternative Options, a Utah adoption agency, to aid with the adoption process. $^{2}$

Fahland was supposed to call Wyatt when she went into labor, but instead she turned off her phone before going to the hospital. ${ }^{3}$ Wyatt called the Potomac Hospital in Woodbridge, VA numerous times in an attempt to get information about his daughter. Finally, Wyatt was informed his exgirlfriend was at the hospital and given birth to his daughter. ${ }^{4}$ However, by the time Wyatt arrived at the hospital, administrators informed him that

${ }^{1}$ See Sarah Netter, Searching for Emma: Father Fights for Daughter Given Up for Adoption, ABC GoOD Morning AMERICA (Apr. 16, 2010), http://abcnews.go.com/GMA/baby-emma-father-fights-daughter-adoption/ story? $\mathrm{id}=10392464 \#$.TrnB1uYb4Ss.

${ }^{2}$ See In re Adoption of Baby E.Z., 266 P.3d 702, 705 (Utah 2011).

${ }^{3}$ Jerry Markon, 'Baby Emma' Case Puts State Adoption Laws Between Father, Child, WASH. POST, Apr. 14, 2010, at A1, available at http:// www.washingtonpost.com/wpdyn/content/article/2010/04/13/AR2010041302 445.html.

${ }^{4}$ See id. at 2.

\section{P a g e $\mid \mathbf{1 2 9}$}

ISSN 2164-7976 (online) • DOI 10.5195/pjephl.2013.42

http://pjephl.law.pitt.edu 
neither Fahland nor the baby were patients. ${ }^{5}$ According to court records, Baby Emma was born at Potomac Hospital on February 10th. A week later, Fahland relinquished her parental rights and allowed the adoption agency to place the child with her prospective parents-in Utah. ${ }^{6}$

On February 18th, a week after the birth of his daughter, Wyatt initiated custody and visitation proceedings with a Virginia Juvenile and Domestic Relations Court. ${ }^{7}$ Before any progress could be made in the Virginia proceeding, the adoptive parents filed a Petition for Adoption in Utah. ${ }^{8}$ As a result, Wyatt was forced to file a second motion, this time with the Utah courts, contesting the adoption and requesting permission to intervene. ${ }^{9}$ The Utah court denied Wyatt's motion on June 11, 2009, stating that he could not intervene because he had waived his right to the child according to Utah law. ${ }^{10}$ Under Utah law, a putative father ${ }^{11}$ only has twenty days to file for custody — a deadline that expired while Wyatt was fighting for custody in Virginia. ${ }^{12}$

${ }^{5}$ See Lisa Belkin, Who Should Have Custody of Baby Emma?, N.Y. TIMES (Apr. 15, 2010), http://parenting.blogs.nytimes.com/2010/04/15/whoshould-have-custody-of-baby-emma/.

${ }^{6}$ See 266 P.3d at 705.

${ }^{7}$ Id.

8 The Petition for Adoption was filed with the Utah Courts on February 23, 2009. Id. at 3.

${ }^{9}$ See id.

${ }^{10} \mathrm{Id}$.

${ }^{11}$ Putative father is the legal term for the alleged father of the child when the parents are not married at the time of birth.

${ }^{12}$ See John Wyatt, Father Fights for Custody of Daughter Who Was Given Up for Adoption Without Consent, HUfFINGTON POST (Apr. 19, 2011), http://www.huffingtonpost.com/2011/08/19/john-wyatt-father-fights_n_931311.html.

\section{P a g e $\mid \mathbf{1 3 0}$}

ISSN 2164-7976 (online) • DOI 10.5195/pjephl.2013.42

http://pjephl.law.pitt.edu 
Despite the Utah proceedings, the Virginia Court recognized Wyatt's right to custody and granted him temporary custody of the infant in December of 2009. The Court held Wyatt was the child's "acknowledged father," had sought custody five days before the adoptive parents filed an adoption petition in Utah, and therefore the child could not be adopted without his consent. ${ }^{13}$ However, by that time, Baby Emma had been living in Utah with her adoptive family for almost a year and Utah refused to recognize the Virginia order. In July 2011, almost two and a half years after Baby Emma's birth, the Utah Supreme Court affirmed the lower court's decision, holding that Wyatt failed to exercise his parental rights before Utah's twenty day deadline expired and, thus, forfeited his right to contest the adoption. ${ }^{14}$ The discrepancies in state's laws has left all the parties involved in limbo for over three years, and John continues his fight.

Regrettably, Baby Emma's story is not unique. Because adoption laws are regulated by the state, there are fifty-one different sets of adoption laws in the United States. ${ }^{15}$ Conflicts between states, such as the fight between Utah and Virginia, are not uncommon because of the discrepancies in adoption laws amongst the states. ${ }^{16}$ These discrepancies between different state

${ }^{13}$ See Markon, supra note 3, at 3.

${ }^{14}$ See Wyatt, supra note 12.

${ }^{15}$ There are adoption laws in each of the fifty states and the District of Columbia.

${ }^{16}$ In the recent past, there have been at least ten cases in which babies were moved to, or born in, Utah and adopted without the consent of an outof-state father. See Netter, supra note 1. According to Joan Hollinger, a University of California at Berkley Professor, Utah's law "make[s] it virtually impossible for an out-of-state father to prevent the adoption of an out-ofwedlock child when the mother is determined to go forward." Belkin, supra note 5. Utah Supreme Court Chief Justice Christine Durham wrote, "Utah risks becoming a magnet for those seeking to unfairly cut off opportunities for biological fathers to assert their rights to connections with their children." O'Dea v. Olea, 217 P.3d 704, 716 (Utah 2009) (Durham, C.J., dissenting)

\section{P a g e $\mid \mathbf{1 3 1}$}

ISSN 2164-7976 (online) • DOI 10.5195/pjephl.2013.42

http://pjephl.law.pitt.edu 
adoption laws lead to confusion, forum shopping, and most importantly, negative attitudes and reactions toward adoption. Ultimately, these discrepancies hurt the only innocent party involved: children in need of a family. As a solution to multiple public health concerns, adoption laws would benefit from a uniform adoption act.

This Note will examine the extensive issues resulting from the discrepancies between state adoption laws and address how a uniform adoption act could significantly promote adoption as a viable solution to two public health concerns: the increasing number of unplanned pregnancies and the significant number of children in foster care awaiting permanent placements. Section I explores public health concerns that would benefit from a uniform adoption act. Section II discusses adoption laws as state responsibilities and addresses the major consequences of having different state adoption laws. Section III details past efforts to overcome the differences in state adoption laws, including the Uniform Adoption Act of 1994. Finally, Section IV analyzes the need for some form of uniform adoption laws if adoption is to remain a viable solution to public health concerns, namely the increasing number of unplanned pregnancies and significant number of children in the foster care system awaiting adoption.

\section{Adoption as a Viable Solution to Public Health Concerns}

Adoption has long been seen as the "perfect solution" for numerous parties. ${ }^{17}$ It is generally viewed as a private matter between the birth family and the prospective adoptive family. Publically, however, adoption is a legal

(The Court ruled in favor of an unwed Wyoming mother who lied to the father by telling him she miscarried and then traveling to Utah to deliver the child and place her for adoption.).

${ }^{17}$ These parties include parentless children, adoptive parents unable to conceive, birth parents unable to conceive or government entities hoping to shift the public costs of caring for independent children onto private individuals. Joan Heifetz Hollinger, The Uniform Adoption Act: Reporter's Ruminations, 30 FAM. L.Q. 345, 345 (1996).

\section{P a g e $\mid 132$}

ISSN 2164-7976 (online) • DOI 10.5195/pjephl.2013.42

http://pjephl.law.pitt.edu 
proceeding during which the court terminates the birth parent's rights and obligations toward the child and passes those rights onto the adoptive parents. ${ }^{18}$ In transferring those rights, adoption accomplishes numerous goals, the most important of which is serving the best interests of countless innocent children.

Traditionally viewed, adoption is no more than a social service procedure; however, viewed more broadly, adoption provides a solution to the public health concerns of unplanned pregnancies and foster care populations. ${ }^{19}$ Public health is defined as the state's legal powers and duties, in collaboration with its partners (e.g. health care, business, the community, the media, and academia), to improve people's lives. ${ }^{20}$ The Department of Health and Human Services stated, "[p]ublic health is defined as what we do collectively to assure conditions in which people can be healthy." ${ }^{21}$ One of the foremost goals of public health law is to "pursue the highest possible level of physical and mental health in the population, consistent with the values of

${ }^{18}$ Lisa M. Simpson, Adoption Law: It May Take a Village to Raise a Child, but It Takes National Uniformity to Adopt One, 3 PHOENIX L. ReV. 575, 578 (2010). See also Adoption of What? Information Policy for Records of Adoption (of People) in the U.S., Rec. MGMT Q., Apr. 1, 1993, at 3. Adoptions may occur for a variety of reasons, including birth parent(s) wanting the child to have a better life than they can provide; a young woman or young couple facing an unplanned and unwanted pregnancy and inability to raise the child; an adoptive parent who is a relative or stepparent of the child; or foster parents choosing to adopt their foster child.

${ }^{19}$ Lorraine V. Klerman, Adoption: A Public Health Perspective, 73 AM. J. Pub. HeAlTh 1158, 1158 (Oct. 1983).

${ }^{20}$ Lawrence O. Gostin, A Theory and Definition of Public Health Law, 10 J. Health Care L. \& POL'Y 1, 1 (2007).

${ }^{21}$ Public Health System, Finance, and Quality Program, U.S. DEPARTMENT OF HEAlTH \& HUMAN SERVICES, available at www.hhs.gov/ ash/initiatives/quality.

\section{P a g e $\mid 133$}

ISSN 2164-7976 (online) • DOI 10.5195/pjephl.2013.42

http://pjephl.law.pitt.edu 
social justice." ${ }^{22}$ In essence, public health law strives to improve the functioning and longevity of populations, including those affected by unplanned pregnancies and foster care.

\section{A. Adoption as a Solution to Health Issues Resulting FROM UNPLANNED PREgNANCIES}

After thirteen years of decline, teen pregnancy rates are once again rising at an alarming rate. ${ }^{23}$ In 1979, roughly 598,000 children were born out of wedlock. By 1991, with fewer stigmas attached to unwed pregnancies, there were over 1,225,000 children born out of wedlock. ${ }^{24}$ There are numerous explanations for the numerical rise of children born out of wedlock and from teen pregnancies. One of the biggest reasons is the changing social stigma attached to teen and single motherhood. This change is the result of unrealistic depictions and portrayals of teen pregnancy in the entertainment fields, including movie and television shows such as Juno, The Baby Borrowers, The Secret Life of the American Teenager, and Teen Mom. ${ }^{25}$

Since adolescent pregnancy and parenting are undeniably acknowledged as public health problems and concerns, adoption presents a viable alternative or solution to the public health concerns that are consequences of unplanned pregnancies. Possible consequences of teen pregnancy can include abortion,

${ }^{22}$ Gostin, supra note 20.

${ }^{23}$ Jenifer Goodwin, Teen Maternity: Birth Rate for Adolescents Is on the Rise Again After 15 Years of Decline, SAN DiEgo UnION-Trib., Sept. 13, 2008, at E1 (Between 1991 and 2003 there was a 34\% decrease in teen births according to the Center for Disease Control and Prevention. However, between 2005 and 2006, the birth rate for teens rose 3\% nationwide, and the increase continued in following years.).

${ }^{24}$ Sarah Clarke Wixson, And Baby Makes Three: The Rights of the Child, the Adoptive Parents and the Biological Parents Under the Uniform Adoption Act, 33 IDAHO L. REV. 481, 486 (1997).

${ }^{25}$ See Goodwin, supra note 23.

\section{P a g e $\mid 134$}

ISSN 2164-7976 (online) • DOI 10.5195/pjephl.2013.42

http://pjephl.law.pitt.edu 
single parenthood or teenage-married parenthood, none of which are ideal. ${ }^{26}$ Adoption presents a possible solution to these difficult situations and equally undesirable consequences. Since Roe v. Wade was decided in 1973, abortion has increased in populating, impacting the role adoption has played in society. ${ }^{27}$ In fact, the number of children available for adoption has decreased significantly with the growing acceptance of abortion and single-parent families. ${ }^{28}$ According to a survey, "the most common reasons women gave [for having an abortion] were a baby would interfere with work or school or they could not afford a child." ${ }^{29}$ Due to the ease of obtaining abortions following Roe $v$. Wade, only $2 \%$ of women facing unplanned pregnancy choose to make an adoption plan. ${ }^{30}$

Government, at both federal and state levels, has treated adoption as a possible solution to the public health concerns of unplanned pregnancies, especially teen pregnancies. In fact, the government has, and is currently dedicating a great amount of resources to countering the harsh views of

${ }^{26}$ Klerman, supra note 19, at 1159.

${ }^{27}$ Beverly Beyettet, Abortion v. Adoption: If the Supreme Court Again Outlawed Abortion, Could the System Handle the Many New Babies?, L.A. Times, Oct. 20, 1988, at View Life and Style.

${ }^{28}$ Jennifer M. Lippold, Note, Transnational Adoption from an American Perspective: The Need for Universal Uniformity, 27 CASE W. RES. J. INT'L. 465, 469 (1995). Before Roe v. Wade, Los Angeles County reported to placing 200-250 infants with adoptive families every month. Since the Roe $v$. Wade decision, the number of adoptions has dropped to 20-30 newborns placed every year. Beyettet, supra note 27.

${ }^{29}$ Beyettet, supra note 27.

${ }^{30}$ Donna S. Ames, Most Prisoners Were Raised in Single-Family Homes, Statistics Show Adoption Option: It All Starts with Mothers Who Will Allow Their Babies to Be Adopted, MoBILE REG., Nov. 16, 2003, at D.

\section{P a g e $\mid \mathbf{1 3 5}$}

ISSN 2164-7976 (online) • DOI 10.5195/pjephl.2013.42

http://pjephl.law.pitt.edu 
adoption and presenting it as a viable alternative to abortion. ${ }^{31}$ Many people, especially young women, are unaware of what adoption truly offers: a degree of openness, aid for maternity-related expenses and the ability to choose their child's adoptive parents. ${ }^{32}$ Most young pregnant women are unaware of the rewards of adoption, most importantly the ability to choose a better future for their child. ${ }^{33}$ If government does not promote adoption, it gives the perception of supporting the ideology that it is permissible to drop out of school, to have children you cannot support, to let the state take custody of the child to raise it, or to have an abortion. ${ }^{34}$

The government has recognized, and in fact has enacted legislation addressing, the importance of promoting adoption as a solution to the public health concern of adolescent pregnancy. Multiple pieces of legislation have been drafted promoting adoption as a viable alternative for pregnant adolescents, and there have been various communications from officials at the U.S. Department of Health and Human Services encouraging the consideration of adoptions. ${ }^{35}$ Further, Congress and the Office of Adolescent Pregnancy Programs (OAPP) have pushed for legislation authorizing OAPP grants for adolescent pregnancy services. This legislation states:

Adoption is a positive option for unmarried pregnant adolescents who are unwilling or unable to care for their

${ }^{31}$ Often adoption is viewed as a harsh punishment for birthmothers. Carol Downer, the founder of the Feminist Women's Health Center in L.A. stated, "The way our society handles adoption amounts to eternal punishment." Beyettet, supra note 27. Bruce Rappaport, director of the National Federation of Open and Independent Adoption Centers reported that, "97\% of young people facing a crisis pregnancy never even considered adoption, put off by a system that makes them feel like 'criminals."' Id.

${ }^{32}$ Ames, supra note 30.

${ }^{33}$ Goodwin, supra note 23.

${ }^{34}$ Ames, supra note 30.

${ }^{35}$ Klerman, supra note 19 , at 1159.

\section{P a g e | 136}

ISSN 2164-7976 (online) • DOI 10.5195/pjephl.2013.42

http://pjephl.law.pitt.edu 
children .... adoption is a means of providing permanent families for such children from available approved couples who are unable or have difficulty in conceiving or carrying children of their own to term. ${ }^{36}$

States have also passed legislation to promote adoption as an option for unplanned or unwanted pregnancies. For example, in 2006 Virginia amended the Virginia Code to provide for a "Choose Life" fund to be used by the Director for the Bureau for Public Health to fund eligible, private, non-profit organizations that promote services to pregnant women who are planning to utilize the alternative of adoption for unplanned pregnancies. ${ }^{37}$ Despite states' attempts to promote adoption as a solution to these public health concerns, the health consequences of unplanned pregnancies or teen pregnancies are still prevalent in today's society.

\section{B. Adoption as a Solution to the Growing Foster Care SYSTEM CONCERNS}

In addition to adolescent pregnancy, foster care is another public health concern for which adoption may offer a solution. The foster care system has attracted attention from child health specialists because the increasing number of foster children aging out of the system and the significant delays children must endure in finding a permanent home is a serious public health concern. ${ }^{38}$ The number of children in foster care has almost doubled in the past fifty years. $^{39}$ As of 2010, more than 400,000 children were in foster care. ${ }^{40}$

${ }^{36} I d$.

${ }^{37}$ H.D. 4507, 77th Leg., Reg. Sess. (W.Va. 2006).

${ }^{38}$ Klerman, supra note 19.

${ }^{39}$ In 1960 , there were roughly 234,000 children in foster care. As of 2010, that number had grown to 408,000. CHIAKI MoRiguCHI ET AL., THE Evolution of Child Adoption IN THE United StATes, 1950-2010: AN ECONOMIC ANALYSIS OF HISTORICAL TRENDS 17 (2010). In 1960, there were

\section{P a g e $\mid 137$}

ISSN 2164-7976 (online) • DOI 10.5195/pjephl.2013.42

http://pjephl.law.pitt.edu 
However, that number has been declining throughout the past decade after reaching a high in the early 2000s. ${ }^{41}$ Despite the decrease in numbers of children living in foster care in the past decade, the number of children living in foster care awaiting adoption (meaning the birth parents have either consented to the adoption or have had their parental rights terminated) has actually increased. According to the U.S. Department of Health and Human Services, in 2003, 119,000 children in foster care were waiting to be adopted. $^{42}$ Today there are over 145,000 children in foster care awaiting adoptive families for permanent placement. ${ }^{43}$

The children living in foster care awaiting adoption have not just become eligible for adoption. ${ }^{44}$ Rather, the majority of those children have

roughly 234,000 children in foster care. As of 2010, that number had grown to 408,000 .

${ }^{40}$ Wixson, supra note 24 , at 481.

${ }^{41}$ In 2000 , it was estimated that 552,000 children were living in foster care. See MoRIGUCHI, supra note 39. As of 2008, the number of children living in foster care had decreased to 463,000. See Marci McCoy-Roth, Madelyn Freundlich \& Timothy Ross, Number of Youth Aging Out of Foster Care Continues to Rise; Increasing 64 Percent Since 1999, FosTERING CONNECTIONS RESOURCE CENTER (Jan. 31, 2010), http://www.fosteringconnections.org/tools/assets/files/Connections_Agingout.pdf.

42 See Foster Care Adoption in the United States: An Analysis of Interest in Adoption and a Review of State Recruitment Strategies, NATIONAL ADOPTION DAY COALITION (Nov. 16 2005), http://www.aecf.org/upload/ publicationfiles/adoption.pdf.

${ }^{43}$ See Christy Obie-Barret, Adopting Foster Children a Win-Win for Families and Kids, REG.-GUARD (Eugene, OR), Nov. 8, 2010, at A7, available at 2010 WLNR 25823731.

${ }^{44}$ Foster children must be "free" for adoption. In order to be eligible for adoption, the biological parents must either consent to the adoption or have their rights as parents terminated. In order for a parent's rights to be terminated, it must be shown that the child has been abandoned, neglected,

\section{P a g e | 138}

ISSN 2164-7976 (online) • DOI 10.5195/pjephl.2013.42

http://pjephl.law.pitt.edu 
been waiting years for a safe, permanent home. Once a child's parent's rights have been terminated, making him eligible for adoption, the child often has to wait a year and a half before his final adoption. ${ }^{45}$ The average time a child spends in foster care is three and a half years. ${ }^{46}$

Long stays in foster care have numerous negative consequences. The delays in finding permanent placement for the child can have significant impacts on a child because without permanent placement, children are not provided the security and stability they require. ${ }^{47}$ The U.S. Department of Health and Human Services has stated, "One of the most profound and intolerable problems in child welfare litigation is that of delay." ${ }^{48}$ Foster care

abused, or the court find that it is in the best interests of the child. See generally ARIZ. REV. STAT. ANN. § 8-533 (2012 West 1996), CAL. FAM. CODE § 7820-24 (1994), and IDAHO CODE § 16-2005 (1996). Until the parent's consent or have their rights terminated by the courts, a child will not be "free" to be adopted, regardless of how long they have been in foster care. See generally In re ELW, 2005 WL 127369, at 1 (Cal. Ct. App. Jan. 31, 2002) (in which the child was taken into protective custody on April 8, 1997, but was not "free" for adoption until almost three years later).

${ }^{45}$ See NATIONAL AdOPTION DAy COALITION, supra note 42. In 2009, roughly 8,000 (or $14 \%$ of all children adopted that year) waited over two years for their adoption to be finalized after their parent's rights had been terminated. Another 16,000 (or 28\%) were forced to wait between one and two years. See Kerry DeVooght, Karin Malm, Sharon Vandivere \& Marci McCoy-Roth, Number of Children Adopted from Foster Care Increases in 2009, Fostering ConNections Resource Center (Feb. 3, 2011), http:// www.fosteringconnections.org/tools/assets/files/Connections_Adoption.pdf.

${ }^{46}$ See NATIONAL Adoption Day COALITION, supra note 42.

${ }^{47}$ Jessica K. Heldman, Court Delay and the Waiting Child, 40 SAN DIEGO L. REV. 1001, 1010 (2003).

${ }^{48}$ Children's Bureau, U.S. Department of Health \& Human SERVICES, COURT PROCESS, available at http://www.acf.dhhs.gov/programs/ cb/pubs/adopt02/02adpt4.htm.

\section{P a g e | 139}

ISSN 2164-7976 (online) • DOI 10.5195/pjephl.2013.42

http://pjephl.law.pitt.edu 
does not provide the same security or stability that comes with having a permanent home.

One of the most damaging consequences of the long delay is the increased likelihood of a child "aging out" of the foster system. When a child ages out, he becomes emancipated from the foster system due to age, reaching adulthood without ever finding a safe, permanent home. The number of children leaving the foster system due to aging out has increased significantly in the past fifteen years. ${ }^{49}$ In $2000,7.1 \%$ of all exits from foster care were due to aging out. In 2008 , that percentage increased to $10 \%{ }^{50}$

Children need a permanent home in order to better develop, and if they age out of the foster care system, they are not given that opportunity. As with the delays, children face significant negative consequences if they are forced to age out of the foster system without acquiring permanent placement. Research has consistently shown aging out results in falling behind in the areas of education, housing, health, and employment. ${ }^{51}$ More specifically, these children are at a higher risk of unemployment, poor educational outcomes, health problems, early parenthood, long-term dependency on public assistance, as well as incarceration and homelessness. ${ }^{52}$ Studies have shown that $25 \%$ of foster children who age out of the foster system do not have a high school diploma or GED. ${ }^{53}$ Further, only less than $2 \%$ of those

${ }^{49}$ DeVooght et al., supra note 45.

${ }^{50}$ McCoy-Roth et al., supra note 41. This represents the national average of all exits due to age outs. Some states experience much higher percentages. In Virginia, 30\% of all exits are due to age-outs. In Maine that percentage slightly lower at $22 \%$. Both Illinois and the District of Columbia have age-out percentage of $21 \%$. Id.

${ }^{51}$ DeVooght et al., supra note 45.

${ }^{52}$ Obie-Barrett, supra note 43.

${ }^{53}$ McCoy-Roth et al., supra note 41.

\section{$\mathrm{P}$ a g e $\mid \mathbf{1 4 0}$}

ISSN 2164-7976 (online) • DOI 10.5195/pjephl.2013.42

http://pjephl.law.pitt.edu 
children were able to finish college. ${ }^{54}$ Over half of the children who age out of foster care have experienced one or more episodes of homelessness and almost $30 \%$ of those children have been incarcerated at some point after aging out. ${ }^{55}$ Finally, children who age out are less likely to have steady employment or health insurance compared to peers with permanent homes, making them more likely to rely on government aid. ${ }^{56}$

Foster care is only meant to be a temporary safety net for children in cases where they are suspected of being neglected or abused. ${ }^{57}$ This aging out defeats the purpose of foster care. The significant delays and increasing number of children being forced to age out of the system has prompted the government into action. The only permanent solution to the problem of aging out of the system is adoption, and the government has consistently recognized the importance of adoption in preventing age outs and the subsequent public health concerns.

There has been continual attention placed on the necessity of finding permanent families for children in foster care by federal and state governments. With the passage of the Adoption Assistance and Child Welfare Act of 1980 (AACWA), federal legislation required the development of comprehensive care plans in an effort to develop principles of permanency planning for children in foster care. ${ }^{58}$ Further, the Act put limits on the

${ }^{54} \mathrm{Id}$. This is compared to the $23 \%$ of youth in the general population who is able to finish college. Id.

${ }^{55} I d$.

${ }^{56} \mathrm{Id}$.

${ }^{57}$ Id.

${ }^{58}$ Children's Bureau, U.S. DeP'T OF Health and Human SERVs., A REPORT TO CONGRESS ON BARRIERS AND SUCCESS FACTORS IN ADOPTIONS FROM FOSTER CARE PERSPECTIVES OF FAMILIES AND STAFF 15 (2007), http:// www.acf.hhs.gov/programs/cb/resource/report-congress-barriers-success.

\section{P a g e $\mid 141$}

ISSN 2164-7976 (online) • DOI 10.5195/pjephl.2013.42

http://pjephl.law.pitt.edu 
eligibility of state funding regarding their foster care services. ${ }^{59}$ More importantly, the AACWA provided funding to states to subsidize the adoption of special needs children. ${ }^{60}$ Additionally, legislation introduced an adoption subsidy program to provide financial assistance to adoptive families. ${ }^{61}$ Although the number of adoptions from foster care increased in the years following the passage of the AACWA, the Act had little effect on slowing the entry of children into foster care. ${ }^{62}$ As a result, the number of children in foster care awaiting adoption continued to rise.

Despite the increase in adoptions following the enactment of AACWA, there were still growing concerns regarding the length of time children are forced to wait in foster care. In 1996, President Clinton directed the U.S. Department of Health and Human Services to outline a specific plan to achieve permanency quicker for foster children and to double the number of foster care adoptions. ${ }^{63}$ In response to President Clinton's directive, the legislature passed the Adoption and Safe Families Act (ASFA). The ASFA was intended to promote adoption and other permanent arrangements for children in foster care. It also established standards for procedures pertaining to adoptions from foster care. ${ }^{64}$ The Act provides for more stringent timelines by requiring states to pursue termination of parental rights if the child has been in foster care for 15 out of the most recent 22 months. ${ }^{65}$

In addition to developing a strategy to reduce the delays children endure in foster care, the ASFA also created an Adoption Incentive Program to

\footnotetext{
${ }^{59} \mathrm{Id}$.

${ }^{60} \mathrm{Id}$. at 16.

${ }^{61}$ MORIGUCHI ET AL., supra note 39, at 4.

${ }^{62}$ ChILDREN'S BuREAU, supra note 58, at 16.

${ }^{63}$ DeVooght et al., supra note 45.

${ }^{64}$ Heldman, supra note 47, at 1016.

${ }^{65}$ ChILDREN'S BuREAU, supra note 58, at 16.
}

\section{P a g e $\mid 142$}

ISSN 2164-7976 (online) • DOI 10.5195/pjephl.2013.42

http://pjephl.law.pitt.edu 
reward states for increasing the number of adoptions of foster children. ${ }^{66}$ The incentive funds $(\$ 4,000)$ are given to states for every adoption made from the foster care system exceeding the overall baseline requirement all states are asked to meet. ${ }^{67}$ In September 2010, the Department of Health and Human Services awarded $\$ 39$ million to 38 states and Puerto Rico for increasing adoptions in $2009 .^{68}$

Immediately following the enactment of the ASFA in 1996, there was a sharp increase in the number of children adopted from foster care. ${ }^{69}$ However, since 2000, the number of adoptions has remained relatively stable; and although the Act did decrease the average time children spend in foster care, the delays before finding permanent placement still last years. ${ }^{70}$

The government has continued to make strides to limit the number of children in foster care awaiting permanent placements by increasing the number of adoptions each year. ${ }^{71}$ Despite these efforts, the legislature is not

${ }^{66}$ DeVooght et al., supra note 45.

${ }^{67}$ CHILDREN'S BUREAU, supra note 58, at 16.

${ }^{68}$ Press Release, U.S. Department of Health \& Human Servs., HHS Awards \$39 Million to States for Increasing Adoptions (Sept. 15, 2010), available at http://www.hhs.gov/news/press/2010pres/09/20100915b.html. This is an increase from the $\$ 35$ million awarded in September 2009. Press Release, U.S. Department of Health \& Human Servs., HHS Awards \$35 Million to States for Increasing Adoptions (Sept. 14, 2009), available at http://ransition.acf.hhs.gov/press/hhs-awards-35-million-to-states-forincreasing-adoptions.

${ }^{69}$ In 2000 , there were over 51,000 children adopted from foster care. This represented a 65\% increase over the 31,000 adoptions reported in 1997 before the ASFA was enacted. See DeVooght et al., supra note 45, at 1.

${ }^{70}$ Id. at $1,4$.

${ }^{71}$ In 2008, the federal legislature passed the Fostering Connections to Success and Increasing Adoption Act, which allows states to offer adopting

\section{P a g e $\mid 143$}

ISSN 2164-7976 (online) • DOI 10.5195/pjephl.2013.42

http://pjephl.law.pitt.edu 
without critics. Professionals have expressed concern that the efforts to increase the number of adoptions and decrease the delays of finding permanent placements for foster children could potentially lead to inadequate protection and preparation of adoptive homes. ${ }^{72}$ Regardless of the criticisms, there is a serious public health concern as a result of the increasing number of foster children aging out of the system and the significant delays children must endure in finding a permanent home.

\section{State Adoption LAWs}

In the United States, the power to establish and administer the legal and procedural systems applicable to the adoption process is granted to the individual states, due to their responsibility to regulate the welfare of children. ${ }^{73}$ Therefore, like other areas of family law, adoption is a statecreated statute. The state assumes the role of a parens patriae ${ }^{74}$ in order to protect the welfare of the children and to seek solutions that best meet the children's needs. ${ }^{75}$ As parens patriae, states strive to achieve two main goals:

assistance to youth between 18 and 21 years of age. This was intended to decrease the number of youth aging out of the foster system. McCoy-Roth et al., supra note 41 , at 3-4.

72 U.S. DeP'T OF HeAlth AND Human SERVS., AdOPTION DisRuPtion AND DISSOLUTION 7 (2012), available at www.childwelfare.gov/pubs/ S_disrup.cfm.

${ }^{73}$ Lippold, supra note 28 , at 470.

${ }^{74}$ Parens patriae is a doctrine by which the state, in its capacity as provider of protection to those unable to care for themselves, has standing to prosecute a lawsuit on behalf of a citizen. BLACK'S LAW DICTIONARY 1221 (9th ed. 2009).

${ }^{75}$ Marja E. Selmann, Note, For the Sake of the Child: Moving Toward Uniformity in Adoption Law, 69 WASH. L. REV. 841, 851-52 (1994).

\section{P a g e | 144}

ISSN 2164-7976 (online) • DOI 10.5195/pjephl.2013.42

http://pjephl.law.pitt.edu 
(1) to have every adoption be socially desirable and (2) to have every adoption be legally incontestable. ${ }^{76}$

Until 1851, adoptions were handled by private legislative acts and informal arrangements. In 1851, Massachusetts became the first state to pass an adoption statute that identified specific requirements for approving an adoption. $^{77}$ The Massachusetts Statute codified the traditional rules of adoption and made adoptions final. ${ }^{78}$ Although the Massachusetts Statute served as a model for the adoption statutes in several other states, enormous regional variations existed. Today, all fifty states and the District of Columbia have different laws specifying the qualifications needed to be eligible as adopting parents, the persons eligible for adoption and the persons/entities with the authority to make adoptive placements. ${ }^{79}$ The development of numerous and significantly different adoption laws have resulted because the states are guided by different priorities, needs, and values. ${ }^{80}$

\section{A. The Discrepancies Between State's Adoption Laws}

The number of interstate adoptions has increased as the mobility of the nation has grown, resulting in conflicts between state adoption laws. ${ }^{81}$ Interstate adoptions occur when there is movement of a child across state lines for the purpose of adoption. ${ }^{82}$ When a child is moved to a recipient state

${ }^{76}$ Lippold, supra note 28, at 473.

${ }^{77}$ Naomi Cahn, Perfect Substitutes or the Real Thing?, 52 DUKE L.J. 1077, 1102 (2003).

${ }^{78}$ Wixson, supra note 24 , at 485.

${ }^{79}$ MARGARET C. JASPER, THE LAW OF AdOPTION 1 (2008).

${ }^{80}$ Selmann, supra note 75 , at 846.

${ }^{81}$ Joan Heifetz Hollinger, The Uniform Adoption Act: Reporter's Ruminations, 30 FAM. L.Q. 345, 351 (1996).

${ }^{82}$ Lippold, supra note 28, at 475.

\section{P a g e | 145}

ISSN 2164-7976 (online) • DOI 10.5195/pjephl.2013.42

http://pjephl.law.pitt.edu 
whose adoption laws are divergent from the laws of the child's birth state, there is the potential for numerous conflicts to arise in areas such as valid consent, transfer or continuation of guardianship over the child, continuing jurisdiction, financing costs, services available to support the placement of the child, and agency administrators. ${ }^{83}$ This Note will focus on the two most significant areas that cause conflicts in intrastate adoptions: consent laws and putative father registries.

\section{Discrepancies Between States' Consent LaWs}

The most disputed issue in interstate adoption cases is the validity of the termination of parental rights and/or the parent's consent to the adoption. ${ }^{84}$ Consent is defined as the agreement by a parent(s), or a person/agency acting in place of a parent, to relinquish all rights and duties with respect for a child. ${ }^{85} \mathrm{~A}$ court cannot approve an adoption without proof that the birth parents have executed voluntary and informed consent, or that the birth parents rights were terminated because of their failure to perform parental responsibilities. ${ }^{86}$

As with all adoption law, consent is regulated by state statutes and not federal law. One of the first issues regarding consent is the time frame in which a birth parent can consent to the adoption of their child. Some states allow formal consent to be executed at any time, including before the child's

${ }^{83} I d$.

${ }^{84}$ Greg Waller, When the Rules Don't Fit the Game: Application of the Uniform Child Custody Jurisdiction Act and the Parental Kidnapping Prevention Act to Interstate Adoption Proceedings, 33 HARV. J. ON LEGIS. 271, 301 (Winter 1996).

${ }^{85}$ JASPER, supra note 79, at 39.

${ }^{86}$ Hollinger, supra note 81, at 39.

\section{P a g e | 146}

ISSN 2164-7976 (online) • DOI 10.5195/pjephl.2013.42

http://pjephl.law.pitt.edu 
birth ${ }^{87}$ However, the majority of states do not allow consent to be given until after the child's birth. ${ }^{88}$ Amongst those states that specify when a parent can consent, sixteen states allow a birth parent to consent immediately after the birth of the child, ${ }^{89}$ while thirty states and the District of Columbia require a waiting period after the birth before the consent can be executed. ${ }^{90}$

A validly executed consent to adopt is intended to be final and irrevocable to ensure a permanent and stable home for the child and his/her family. The right of birth parents to revoke their consent is severely limited; however, those limits also vary from state to state. In some states, revocation of consent is permitted for any reason within a few days of giving said

${ }^{87}$ See Selmann, supra note 75 at 867 n.90; see, e.g., ALA. CODE $§ 15$ A26-10A-13 (1992); WASH. REV. CODE § 26.33.080(3) (1992); HAW. ReV. STAT. § 571-61 (1993) (allowing consent to be given following the sixth month of pregnancy).

${ }^{88}$ See Selmann, supra note 75, at 867 n.92; see, e.g., ARIZ. REV. STAT. $\S 8-107$ (B) (1989) (consent can be given no sooner than 72 hours after birth); CONN. GEN. STAT. $\S 45 \mathrm{a}-17$ (consent cannot be given within the first 40 hours); and LA. REV. STAT. § 9-422-7 (consent cannot be given any sooner than the fifth day after birth).

${ }^{89}$ The sixteen states include Alaska, Arkansas, California, Colorado, Delaware, Georgia, Indiana, Maine, Maryland, Michigan, North Carolina, North Dakota, Oklahoma, South Carolina, Wisconsin, and Wyoming. JASPER, supra note 79 , at 41 .

${ }^{90}$ The waiting periods can be anywhere from 12-hours (Kansas) or 24hours (Utah) to 10 days (California and Washington) or 15 days (Rhode Island). The most common waiting period is 72 hours. Fifteen states and the District of Columbia have waiting periods of 72-hours. These states include Arizona, Illinois, Iowa, Kentucky, Minnesota, Mississippi, Montana, Nevada, New Hampshire, New Jersey, Ohio, Pennsylvania, Tennessee, Virginia, and West Virginia. Id.

\section{P a g e $\mid 147$}

ISSN 2164-7976 (online) • DOI 10.5195/pjephl.2013.42

http://pjephl.law.pitt.edu 
consent. ${ }^{91}$ Other states consider consent revocable up until the final adoption decree is granted. ${ }^{92}$ On the other end of the spectrum, consent can be deemed final and irrevocable unless there is a showing of fraud or duress ${ }^{93}$ or if the court determines it is in the best interest of the child. ${ }^{94}$

\section{Discrepancies Between State's Laws on Putative FATHER REGISTRIES}

Discrepancies between putative father notification laws create many contested adoptions. Since the 1960's there has been a dramatic increase in the number of births that occur out-of-wedlock, resulting in a growing number of putative fathers who are seeking to play a role in their children's upbringing. ${ }^{95}$ Due to the increasing number of putative fathers fighting for custodial rights of their children, the U.S. Supreme Court has affirmed constitutional protections for putative fathers' paternal rights when they have established a substantial relationship with their child. ${ }^{96}$

In most jurisdictions, putative fathers are entitled to notice of the adoption proceedings before the termination of his parental rights. Some states require mothers to publish notice of adoption to every potential father if

${ }^{91}$ See, e.g., ALASKA STAT. $§ 25.23 .070$ (1991) (permitting consent to be revoked for any reason within 10 days after the consent is executed).

${ }^{92}$ See, e.g., 23 PA. CONS. STAT. § 2711(c) (Supp. 1996) and TEX. FAM. CODE $\S 162.011$ (1996).

${ }^{93}$ See, e.g., AlA. CODE $§ 26-10 A 13$ (1992); N.H. REV. STAT. $§ 170-\mathrm{b}: 10$ (1994); N.J. STAT. § 9:3.47(d) (Supp. 1996).

94 See e.g., ARIZ. REV. StAT. 8-106(D) (Supp. 1996); Fla. StAT. $\S 63.082(5)$ (1995); W. VA. CODE $\S$ 48-22-305(a)(2) (1996).

95 JASPER, supra note 79, at 44.

${ }^{96}$ See Stanley v. Illinois, 405 U.S. 645 (1972); Quillion v. Walcott, 434 U.S. 246 (1978); Lehr v. Robertson, 463 U.S. 248 (1983).

\section{P a g e | 148}

ISSN 2164-7976 (online) • DOI 10.5195/pjephl.2013.42

http://pjephl.law.pitt.edu 
she cannot locate him. ${ }^{97}$ However, to be entitled to such notice, states generally require the father to register with the state's putative father registry or acknowledge paternity within a certain time frame and registry rules differ from state to state. ${ }^{98}$ These laws force putative fathers to come forward and file to establish paternity if they wish to maintain any right with respect to the child. ${ }^{99}$ In states implementing putative father registries, unwed fathers who fail to register in the prescribed manner within the statutory time period lose their right to consent and/or their ability to contest the adoption.

The differences in putative father registry laws can have numerous consequences. It can be an extreme invasion of privacy for a birth mother "if she is required to disclose intimate personal information even when the father cannot be located." ${ }^{100}$ Further, a birth mother may search for a family in a state with the least restrictive birth father laws so as to avoid having to get his consent. These mothers may decide against adoption because they may feel there are too many requirements to follow in order to comply with the laws of multiple states. Ultimately, the disparity in birth father notification laws prevents predictability as to which law will apply in the event of a contested adoption. $^{101}$

${ }^{97}$ See, e.g., ARIZ. REV. STAT. § 8-106(G) (2008).

${ }^{98}$ JASPER, supra note 79, at 45.

${ }^{99}$ Adoption Act (1994) Summary, Uniform Law Commission: The National Conference of Commissions on Uniform State Laws, available at http://www.uniformlaws.org/ActSummary.aspx?title=Adoption $\% 20$ Act $\% 20$ (1994).

${ }^{100}$ Simpson, supra note 18 , at 582.

${ }^{101}$ See generally In re Baby Girl P, 802 A.2d 1192, 1193-94 (N.H. 2002) (finding where an Arizona birth mother placed her child up for adoption in New Hampshire and despite the father's challenge under Arizona law, the court applied New Hampshire adoption law).

\section{P a g e $\mid \mathbf{1 4 9}$}

ISSN 2164-7976 (online) • DOI 10.5195/pjephl.2013.42

http://pjephl.law.pitt.edu 


\section{B. Consequences of Discrepancies BetWeEn STATE AdOPTION LAWS}

A lack of uniformity between state adoption laws result in a number of negative consequences, all of which deter the government's attempts to portray adoption as a solution to public health concerns resulting from adolescent pregnancies and foster care. The increasing mobility of society makes interstate adoptions extremely common. When a birth parent resides in one state and the adopting family resides in another state, a multitude of issues can occur. Since there is no uniformity between state adoption laws, there are no clear answers when conflicts arise.

The lack of uniformity increases the time and cost of an adoption because states must determine which state's laws apply and can often face conflicting state orders. ${ }^{102}$ An essential problem with the disparity in state laws is the uncertainty as to which state laws apply in the event of a dispute. ${ }^{103}$ In other words, if consent is being disputed in a case involving parents residing in one state and prospective parents residing in a second state, which state's consent laws should be applied? Considering the example of John Wyatt referred to previously, it is easy to see how conflicts between state adoption laws can occur. More importantly, the unpredictability resulting from discrepancies between state adoption laws may make it difficult for the birthmother to rely on an adoption plan as an alternative to her unwanted pregnancy.

Further, the disparity in adoption laws can encourage forum shopping. Adoptive parents may go where they are likely to find a child, where it is easier to satisfy state's standards for parental fitness, and where they are able to acquire a speedy termination of the birth parent's parental rights. ${ }^{104}$ The birth parents, however, may go where they have the greatest say in choosing

${ }^{102}$ Selmann, supra note 75 , at 847.

103 See Simpson, supra note 18, at 577.

${ }^{104}$ Id. at 847.

P a g e | 150

ISSN 2164-7976 (online) • DOI 10.5195/pjephl.2013.42

http://pjephl.law.pitt.edu 
the adoptive parents, where expense reimbursement is highest, and where the father's rights can be terminated with minimal notice. ${ }^{105}$ The result of forum shopping is that some states have become known as baby markets while other states are avoided. ${ }^{106}$ The conflicts arising because of the discrepancies in state adoption laws significantly deter the government's aim of promoting adoption as a solution to the aforementioned public health concerns.

The ultimate consequence resulting from the disparity between state adoption laws is the disruption of an adoption. A disruption occurs when the adoption process ends after the child is placed in an adoptive home and before the adoption is legally finalized, resulting in the child's return to, or reentry into, the birth parent's home or foster care. ${ }^{107}$ Disruptions occur at an alarming rate. It is reported that $10 \%$ to $25 \%$ of adoptions end in disruption. ${ }^{108}$ When such a high percentage of adoptions end in disruption, it is not surprising that all parties involved are wary of adoptions.

\section{The UnIform AdOPTION ACT OF 1994}

The Uniform Adoption Act of 1994 came about because the discrepancies between the state adoption laws led to numerous costly and time-consuming court disputes. The 1990s were filled with stories such as that of Baby Richard, ${ }^{109}$ Baby Emily, ${ }^{110}$ and Baby Clausen. ${ }^{111}$ Following this

${ }^{105}$ Simpson, supra note 18 , at 577.

106 Texas has been called by some professionals as the "Texas Baby Train" due to the relatively unrestricted financial support for birth mothers and the irrevocable relinquishment of parental rights. Id. at 867 n.46. Conversely, California is avoided because of the length of time before adoptions are finalized and the ease with which biological parents can revoke their consent. Id. at 867 n.47.

${ }^{107}$ U.S. DEP'T OF HEALTH \& HUMAN SERVS., supra note 72.

${ }^{108} \mathrm{Id}$.

${ }^{109}$ In re Adoption of Doe, 638 N.E.2d 181 (Ill. 1994) (After a four-year court battle, the Illinois Supreme Court awarded to custody to the birth father,

\section{P a g e $\mid 151$}

ISSN 2164-7976 (online) • DOI 10.5195/pjephl.2013.42

http://pjephl.law.pitt.edu 
tumultuous period, the National Conference of Commissioners on Uniform State Laws (NCCUSL) drafted the Uniform Adoption Act of 1994.

Due to the discrepancies between state adoption laws, adoption was a "prime candidate for a model act." 12 The first attempts to create uniformity in adoption laws were made by the American Bar Association and the NCCUSL in 1953, through the approval of a Uniform Adoption Act, revised in 1969 and amended in 1971. ${ }^{113}$ In 1979, the Model Adoption Legislation and Procedures Advisory Panel submitted a Model State Adoption Act. This was followed by the Model State Adoption Act written by the Family Law Section of the American Bar Association a few years later, which was never approved by the ABA. ${ }^{114}$ The final attempt at unifying adoption laws came from the NCCUSL in the form of the Uniform Adoption Act of 1994 (UAA).

even though the child had been with the prospective parents since birth, because the father was not given proper notice to consent.).

${ }^{110}$ In re Adoption of Baby E.A.W., 658 So. 2d 961 (Fla. 1995) (The court held it was contrary to the child's best interest to disturb the adoption decree after the child had lived with the adoptive parents for 18 months and due to the father's lack of emotional support, his consent was not required.).

${ }^{111}$ See generally Matter of Clausen, 501 N.W.2d 193 (Mich. Ct. App. 1992), aff'd sub nom. In re Clausen, 502 N.W.2d 649 (Mich. 1993) (The court held that the child's prospective parents, and temporary custodians, whose adoption petition was denied when the custody was awarded to the natural parents, lacked standing to litigate regarding custody of the child.).

112 Jonathan G. Stein, Lead Article, A Call to End Baby Selling: Why the Hague Convention on Intercountry Adoption Should Be Modified to Include the Consent Provisions of the Uniform Adoption Act, 24 T. JEFFERSON L. REV. 39, 53 (Fall 2001).

${ }^{113}$ Mishannock Robbins Arzt, In the Best Interests of the Child: The Uniform Adoption Act, 25 STETSON L. REV. 835, 839 (1996).

${ }^{114}$ Selmann, supra note 75 , at 848-49.

\section{P a g e $\mid 152$}

ISSN 2164-7976 (online) • DOI 10.5195/pjephl.2013.42

http://pjephl.law.pitt.edu 
The UAA was the result of five years of proposals and amendments by the NCCUSL, ${ }^{115}$ as well as advice from a variety of interest groups. ${ }^{116}$

The stated purpose of the UAA is to "create a coherent framework for legitimizing and regulating both direct-placement and agency-supervised adoptions ... [and to] facilitate the completion of consensual adoptions and expedite the resolution of contested adoptions." ${ }^{117}$ The goal of the UAA "is to promote the welfare of minor children by ensuring that they will be raised by birth or adoptive families who are committed to and capable of caring for them, and by facilitating only those adoptive placements that are generally conducive to the child's welfare." ${ }^{118}$ It was designed to balance the legitimate interests of all parties: the birth parents, the prospective parents, and the children, ${ }^{119}$ and was intended to be a comprehensive statute addressing all areas of adoption law. ${ }^{120}$ The strength of the UAA lies in its effort to be specific. "It attempts to address all the potential issues that may arise in the course of an adoption." ${ }^{121}$ Ultimately, the UAA attempts to protect children from unnecessary separation from their birth parents and against harmful delays during the adoption process.

In drafting the UAA, the NCCUSL attempted to develop a framework that would best protect each member of the adoption proceeding, particularly

${ }^{115}$ The Uniform Law Commission is appointed by state governments to research, draft, and promote the enactment of uniform state laws, but it is ultimately the state legislatures, not the NCCUSL, that determine need for uniformity. Selmann, supra note 75, at 849-50 n.50 (1994).

${ }^{116}$ Arzt, supra note 113, at 840 .

${ }^{117}$ UAA, 9 ULA 11, 14 (1994, Supp. 2002).

${ }^{118}$ Hollinger, supra note 81 , at 355.

${ }^{119}$ Adoption Act, supra note 99.

${ }^{120}$ JASPER, supra note 79.

${ }^{121}$ Arzt, supra note 113 , at 886.

\section{P a g e $\mid 153$}

ISSN 2164-7976 (online) • DOI 10.5195/pjephl.2013.42

http://pjephl.law.pitt.edu 
the children. ${ }^{122}$ The UAA "aims to facilitate consensual adoptions, expedite the resolution of contested proceedings, standardize procedures for obtaining valid parental consents or relinquishments, and bolster the finality of adoptions." $^{123}$

This is not to say the UAA is without criticisms. An important, relevant, issue is the fact that the UAA largely ignores the number of children in foster care. ${ }^{124}$ Further, the UAA does not mandate the use of public funds for child welfare programs, nor does it deal with social services to dependent and foster children. ${ }^{125}$ Despite its best intentions, the UAA has failed to attract the attention of state legislatures. The UAA is a model act and can be introduced and passed in whole or in part by state legislatures. ${ }^{126}$ Today, only Vermont has modeled its adoption laws in large part on the UAA. ${ }^{127}$

\section{UNIFIED LAWS ARE NEEDED FOR AdOPTION TO BE A SOLUTION FOR Public HeAlTh CONCERNS}

Unified adoption laws are necessary to overcome the conflicts in adoption proceedings resulting from the discrepancies in individual state laws. The inconsistencies between state adoption laws make all parties vulnerable - the birth parents, the adoptive parents, and most importantly, the children. The confusing and conflicting adoption laws discourage many

${ }^{122}$ Stein, supra note 112, at 53.

${ }^{123}$ Joan Heifetz Hollinger, Analysis of the Proposed Uniform Adoption Act (UAA) of 1994, in FAMILIES BY LAW: AN ADOPTION READER 37, 47 (Naomi R. Cahn \& Joan Heifetz Hollinger eds., 2004).

${ }^{124}$ Carrie L. Wambaugh, Comment, Biology Is Important, but Does Not Necessarily Always Constitute a "Family": A Brief Survey of the Uniform Adoption Act, 32 AKRON L. REV. 791, 827 (1999).

${ }^{125}$ Hollinger, supra note 81, at 352-53.

${ }^{126}$ JASPER, supra note 79.

${ }^{127}$ Wambaugh, supra note 124 , at 792.

\section{P a g e | 154}

ISSN 2164-7976 (online) • DOI 10.5195/pjephl.2013.42

http://pjephl.law.pitt.edu 
potential birth and/or adoptive parents, especially when they are forced to decipher multiple state laws. According to estimates by the National Council for Adoption, at least two million people would like to adopt, and yet only 50,000 adoptions occur annually. ${ }^{128}$ Further, despite the increase in number of women who are interested in adoption, ${ }^{129}$ women are actually less likely to take actual steps to adopt. ${ }^{130}$ The unpredictability makes it difficult for a birth mother to rely on adoption as a viable solution to an unplanned pregnancy. Additionally, it makes it difficult for prospective parents to decide to become both financially and emotionally invested in the adoption process. A child's need for swift and permanent placement in a loving home is thus compromised, often irreparably, by conflicting state statutes.

By unifying adoption laws, the complexity existing because of the disparity in state adoption laws would cease. "One way to solve the problem of arbitrariness in the determination of jurisdiction is to negate the substantive effects of the determination." ${ }^{131}$ For instance, to the degree that the standards of consent are the same from state to state, the consequences of fighting a dispute in one jurisdiction as opposed to another will be minimized. Uniformity in adoption laws would allow a birth mother to place her child with an adopting family in any state without the fear of potential conflict in laws. However, to ensure success, all states must enact the same legislation.

Greg Waller stated, "[n]o solution is perfect, but imperfection should not be allowed to forestall efforts to implement legislation that will best serve the

${ }^{128}$ Wixson, supra note 24 , at $481 \mathrm{n} .2$.

${ }^{129}$ Between 1995 and 2002, women's interests in adoption rose 38\%, from 13 million women being interested in adoption in 1995 to 18 million reporting an interest in 2002. NATIONAL ADOPTION DAY COALITION, supra note 42 , at 7 .

${ }^{130}$ In $1995,16 \%$ or 2.1 million women who reported an interest in adoption took steps to adopt. By 2002, that number had decreased to $10 \%$ or 1.9 million. Id. at 10 .

${ }^{131}$ Waller, supra note 84 , at 304.

\section{P a g e $\mid 155$}

ISSN 2164-7976 (online) • DOI 10.5195/pjephl.2013.42

http://pjephl.law.pitt.edu 
interests of children in adoptive custody disputes." ${ }^{132}$ As it stands, the stateby-state adoption laws only serve to hinder the adoption process. In doing so, it is also deterring the government's promotion for adoption to be a solution for public health concerns. The result of national uniform adoption laws will be a more predictable, efficient and fair adoptive system. The UAA as written is not necessarily the best solution. Certain aspects need to be redrafted, especially to add provisions regarding foster child adoptions, if it is going to promote adoption as a solution to the public health concerns relating to unplanned pregnancy and foster care. The necessity for a uniform law was recognized in the early 1990s and is still needed today. Without a uniform adoption law, the conflicts in adoptive proceedings will continue to deter people from entering into the adoption process for children from unplanned pregnancies or the foster care system.

\section{CONCLUSION}

John Wyatt began his fight in February 2009, just after his daughter's birth. The Utah Supreme Court just handed down a decision July 2011, and Mr. Wyatt claims he is not done fighting. There is no valid reason for an adoption proceeding, for a child's life, to be in limbo for three or more years.

The government has gone to great lengths and has utilized many resources in promoting adoption as a solution for the public health concerns of unplanned pregnancies and the foster care system. In order for the government to be successful in its efforts, the conflicts that occur because of disparities between state adoption laws must cease to exist. One judge stated, "[u]ncertainty ... breeds litigation which, regardless of how the issues are ultimately decided by the courts, often results in tragedy for the child." 133 With the ever-increasing ease of mobility, the number of interstate adoptions is only going to grow. Conflicts between states cast adoption in a negative light and discourage potential adoptive families and birth parents from

\footnotetext{
${ }^{132}$ Id. at 313.

${ }^{133}$ In re Anderson, 99 Idaho 805, 818 (1978) (Bakes, J., dissenting).
}

\section{P a g e $\mid 156$}

ISSN 2164-7976 (online) • DOI 10.5195/pjephl.2013.42

http://pjephl.law.pitt.edu 
considering adoption as a viable alternative. The secret to ending the heartbreak and turmoil of contested adoptions is prevention. A uniform adoption act would severely limit the number of challenges to adoptions, therefore promoting adoption as a successful alternative to public health concerns such as adolescent pregnancies and foster care. 